Article

\title{
Pentecostalization and Politics in Paraguay and Chile
}

\author{
Henri Gooren \\ Department of Sociology, Anthropology, Social Work and Criminal Justice, Oakland University, Rochester, \\ MI 48309, USA; gooren@oakland.edu
}

Received: 13 July 2018; Accepted: 31 October 2018; Published: 3 November 2018

\begin{abstract}
This article analyzes Pentecostal churches in Paraguay and Chile, tracing how their older ethos of politics as worldly and corrupt is gradually changing and why. It explores changing church-state relations and conceptions of political culture and citizenship among Pentecostal members and leaders, and assesses some mutual influences that Pentecostal and mainstream Protestant churches exert on each other. Chile has the oldest autochthonous Pentecostal churches of Latin America, whereas Pentecostal growth only recently started in Paraguay, providing a contrast in levels of Pentecostalization. The article develops a general overview of modes of (in)direct involvement of Pentecostal leaders and members in national politics by assessing the risks and advantages of five possible positions.
\end{abstract}

Keywords: Pentecostalism; Pentecostalization; politics; Paraguay; Chile

\section{Introduction}

This article analyzes Pentecostal churches in Paraguay and Chile, tracing how their older ethos of politics as worldly and corrupt (Lalive d'Epinay 1969, p. 114; Fediakova 2004, p. 277) is gradually changing and why. It explores changing church-state relations and conceptions of political culture and citizenship among Pentecostal members and leaders, and assesses some mutual influences Pentecostal and mainstream Protestant churches exert on each other. Hence, this article complements the literature on the consequences of Pentecostal growth for different Latin American societies. It also follows the early research advice of (Levine 1986, p. 99) to begin with "what religious groups and people actually do."

Paraguay and Chile represent the extremes of Pentecostal growth in Latin America. Chile has the oldest autochthonous Pentecostal churches in Latin America, whereas Pentecostal growth only started in the 1980s in Paraguay, providing a contrast in levels of Pentecostalization, a term that refers to the combination of Pentecostal numerical growth, Pentecostal influence on other religions, and/or Pentecostal impact on the rest of society, including politics (Gooren 2010b). Using ethnographic field research, participant observation, semi-structured interviews, and surveys, I studied Pentecostal and non-Pentecostal churches and organizations in Asunción, Paraguay (2010 and 2012) and Santiago de Chile (2011). Seven trained research assistants (undergraduate students at two local universities) and I conducted 188 formal semi-structured interviews with 48 experts and 140 church members using the same interview protocols. In each country, I visited ten different churches and, together with local experts, selected an illustrative sample of congregations for in-depth study through participant observation and interviews. This meant that I went to Sunday meetings and other events for at least a month, conducted interviews with leaders and members, collected books and brochures, watched Pentecostal TV programs, and analyzed the contents of church websites. Interviews with church members and leaders as well as local experts were coded by topic and triangulated with other coded data from books, brochures, websites, and participant observation. A total of nine religious congregations were studied in-depth: five in Asunción (Centro Familiar de Adoración, Más que Vencedores, 
a Pentecostalizing Mennonite congregation, and two charismatic Catholic parishes), and four in Santiago de Chile (a Vineyard and a Pentecostalizing Anglican congregation, and two charismatic Catholic parishes). My fieldwork research allows me to present the unique voices of church members and a dozen congregational leaders from Paraguay and Chile and their perspectives on the connections between (their) churches and politics.

Chile is the birthplace of autochthonous Pentecostalism in Latin America; the Iglesia Metodista Pentecostal (IMP), the country's biggest Pentecostal church, was already underway by 1909 . Pentecostalism in Chile exploded in the 1920s and 1930s, stabilized in the 1960s, and exploded again in the 1970s and 1980s during the Pinochet dictatorship (1973-1990). ${ }^{1}$ Protestants currently make up over one-fifth of the total Chilean population, which ranks among the higher percentages in Latin America (Mandryk 2010, p. 46), and the vast majority of them-approximately 85 percent-are Pentecostals (Parker 2000, p. 624). Political involvement by Pentecostal members and leaders, however, is low in Chile in contrast to Brazil. Chile has "no major Protestant political parties and few examples of Protestants elected to major public office" (Patterson 2005, p. 7). This article will explain why.

Pentecostal growth in Paraguay started as late as the 1980s, during the final years of the Stroessner dictatorship (1954-1989), and has continued until the present day. In 2002, Pentecostals made up only 3 percent of the Paraguayan population, with mainstream Protestants, especially Mennonites and Lutherans, accounting for another 3 percent. $^{2}$ By 2009, Pentecostals made up 4.6 percent of the population and mainstream Protestants 5.4 percent (Mandryk 2010, p. 676). The influence of Pentecostalism, however, is greater than these numbers suggest, since popular elements of the movement are starting to find their way into mainstream Protestantism. Many Baptist and especially Spanish-speaking Mennonite churches in Asunción are "Pentecostalizing". They use Pentecostal songs and worship styles, although they stop short of allowing members to speak in tongues. Furthermore, in the Protestant community overall, the two most successful churches in terms of membership growth are both Pentecostal. Más que Vencedores, started by Emilio Agüero in 2001, specializes in targeting young people. The Centro Familiar de Adoración (the only megachurch in Paraguay) started in 1985 and successfully appeals to families, thanks to its charismatic leader Emilio Abreu, its sophisticated evangelization methods, and its extensive use of mass media. The Pentecostalization process in Paraguay has made significant advances, then, although it remains in its initial phase, making the question of how Paraguayan Pentecostals view political involvement particularly interesting and offering a perspective on how these processes unfold over time.

It is imperative to place any analysis of political involvement in Paraguay and Chile in a larger comparative context. Paul Freston has studied the wider topic of church-politics relations for over two decades, resulting in important books on evangelicals and politics in the Global South and on Protestant political parties. He also stressed the need for "more detailed country-level studies" (Freston 2001, p. 281). Freston developed a four-fold typology of Protestant modes of national-level political involvement worldwide (Freston 2001, p. 285 ff.):

While universalist concerns such as human rights and democracy predominate among some actors, the practice of many is reducible to an ecclesiastical corporatism which seeks to enlist state resources for church aggrandizement (Assemblies of God and Universal Church in Brazil); or to a political imitation of the dominant actor in the religious field, whether Catholicism or Islam (Iglesia Metodista Pentecostal in Chile, much Pentecostalism in Nigeria); or to a triumphalism which talks of a divine right of evangelicals to govern (Guatemala, Zambia).

1 (Cleary and Sepúlveda 1997, p. 100); (Gooren 2015, pp. 208-9). The Protestant percentages in Chilean censuses since 1907 are: 1907, 1 percent; 1920, 1.4 percent; 1930, 1.5 percent; 1940, 2.3 percent; 1952, 4.1 percent; 1960, 5.6 percent; 1970, 6.2 percent; 1992, 13.2 percent; 2002, 15.1 percent (Cleary and Sepúlveda 1997, p. 106; Masías-Hinojosa et al. 2008, p. 3). For 2009, (Mandryk 2010, p. 210) reported 20.9 percent: 11.7 percent mainline Protestants and 9.2 percent Pentecostals.

2 (Holland 2006, p. 205). (Johnstone and Mandryk 2001, p. 514) reported 5 percent mainline Protestants and 3.6 percent Pentecostals for 2000. 
(Freston 2001, p. 305) concluded that corporatism and triumphalism are "clearly prejudicial to democracy." He saw corporatism as typical for evangelical leaders in Brazil and Central America (see, e.g., Gooren 2010a), triumphalism as typical of Presidents Ríos Montt and Serrano in Guatemala, and political imitation of the dominant Roman Catholic Church as uniquely typical of Chile's Iglesia Metodista Pentecostal. While Freston acknowledged the role of theology, he did not explore the main motivations for why churches and their leaders do or do not get involved in politics, which is what I will do here.

This article proposes an overview of five possible modes for direct or indirect involvement of Pentecostal leaders and members in national politics, each with its own risks and advantages. These are descriptive options that I derived from my fieldwork observations in these Pentecostal congregations in Paraguay and Chile. I will distinguish patterns that run from low risk and low involvement to high risk and high involvement. First, the low-risk position involves staying focused on a core evangelical teaching: converting as many people as possible, with the expectation that this should eventually result in positive changes in politics and society, while fulfilling one's civic duties by voting during elections. ${ }^{3}$ The second option limits the mobilization of the faithful to key moral-ethical issues like divorce, abortion, and same-sex marriage, often in alliance with conservative Roman Catholics. Third, churches may mobilize the faithful around religious or political leaders who are thought to exemplify biblical principles and set a moral example, and who explicitly campaign against corruption in politics. The fourth option endorses the direct political involvement of church members, as exemplified by Ernst Bergen, a Mennonite businessman who served as a minister in Paraguay's Duarte government (2003-2008). Finally, the fifth course of action involves church leaders getting directly involved in politics as office holders, as occurred in Guatemala with General Efraín Ríos Montt (1982-1983) and President Jorge Serrano (1991-1993). I will use these five options to analyze and understand Pentecostal involvement in politics in Paraguay and Chile in historical and contemporary perspective.

\section{The Old Ethos: Protestantism and the State in Paraguay and Chile}

Protestantism originally developed in Paraguay as an embattled minority, persecuted by Catholics until as late as the 1960s and struggling to win official state recognition. Furthermore, Pentecostalism, for its part, reached Paraguay relatively late. The Philadelphia Evangelical Church arrived in 1938, followed by the Assemblies of God in 1945. The Church of God (Cleveland, TN) started its mission work in 1954. For many years, Pentecostal success was very limited. More successful was a unique local brand of Pentecostalism, El Pueblo de Dios (The People of God), founded in 1963 as an independent church. The latest Pentecostal church from the United States arrived in 1985: the Foursquare Gospel Church. The biggest Pentecostal churches were the Assemblies of God, the Iglesia de Dios del Paraguay, and the Iglesia Evangélica Asamblea de Dios Misionera. Paraguay experienced the highest Pentecostal growth in the 1980s and again after 2002 (Gooren 2013).

For most of their history, the dominant attitude of Pentecostals and other Protestants toward politics was one of abstinence (Plett 1988, p. 131; Duarte 1994, 2001). Protestant leaders were pleased when dictator Stroessner reiterated the importance of religious freedom in 1967 (Plett 1988, p. 103). In return for the freedom of religion and official state recognition they had long yearned for, they stayed out of politics, which was deemed corrupt and worldly. The legacy of foreign mission churches also depoliticized the Protestant leadership and supported a theology of separation from society. This created a clear contrast with the Roman Catholic Church, which historically sided with the elites

3 (O'Neill 2010, p. 160) reported that neo-Pentecostals believed that Guatemala can only change though conversion, individual repentance, Bible study, and hard work, which open the believer to the "values of progress: punctuality, responsibility, and cleanliness." However, members of the mega-church El Shaddai "are more likely to pray for Guatemala than pay their taxes; they tend to speak in tongues for the soul of the nation rather than vote in general elections; and they more often than not organize prayer campaigns to fight crime rather than organize their communities against the same threat" (O'Neill 2010, pp. xvi, 201). 
but had, since the 1960s, moved toward "a preferential option for the poor" (Gooren 2002, p. 29ff.). As some bishops gradually became more political in the 1970s and 1980s, emphasizing human rights and confronting Stroessner, the Protestant and Pentecostal leadership continued their earlier position of being "apolitical".

Just as in Paraguay, an ethos separating the church and "the world" (including the state) prevailed among the Pentecostal churches in Chile. The Iglesia Metodista Pentecostal (IMP) and the Iglesia Evangélica Pentecostal (IEP), which together dominated the Protestant community there (Johnstone and Mandryk 2001, p. 156), shared "a passive ethic that proclaims total separation from the world" of politics and education (Sepúlveda 1988, p. 300). This ethos is typical of classical Pentecostalism and of mission churches in general, and it clearly hampered efforts by some progressive leaders and members to become more involved in Chilean society in the 1960s and early 1970s. Yet the authoritarian structure of the IMP allowed its conservative leaders to lend legitimation to the Pinochet military government through a Pentecostal "Te Deum," first celebrated in their new Jotabeche "cathedral" in 1974. This created tensions that eventually resurfaced in leadership struggles following the death of Bishop Vásquez in 2003 (see below).

The old Pentecostal political ethos is nicely summarized by a middle-aged male member of the Methodist Pentecostal Church (IMP) in San Ramón, Santiago:

I believe that the orientation of the practicing Christians in Chile is not about establishing a presence in society. It's to influence society to turn back to God, to improve the quality of life, to live with morality, with respect, according to what the Word of the Lord states. I personally believe that the church ... I don't believe we want to interfere with the political parties. ${ }^{4}$

This is a perfect expression of the first position in my overview of modes of political involvement of Pentecostal leaders and members: focusing on the core task of converting as many people as possible to their church, hoping that through conversion they will have a change of heart and become better people, which in turn will make the country a better place. It is the position that used to be shared by the majority of Protestants and Pentecostals in Latin America, including Chile and Paraguay. To explain its origins, we need to look at history.

\section{Protestantism, Political Parties, and Electoral Campaigns}

Whereas Chilean Catholicism even before Vatican II (1962-1965) was more progressive than elsewhere in Latin America (Barrett et al. 2001, pp. 187-88), Chilean autochthonous Pentecostalism (IMP, IEP, and their subsequent schisms) was dominated from the start by the traditional ethos proclaiming total separation from the world (Sepúlveda 1988, p. 300). Based on these radically different theological origins, more societal involvement from Catholics than Pentecostals was to be expected.

Yet Fediakova identified two factors that have facilitated greater political involvement of Pentecostals since the 1970s: (1) the need to protect their institutional interests (Freston's corporatism), especially during the Pinochet dictatorship (1973-1990), and (2) the development of Chilean civil society after the return to democracy in 1990. As relations between General Pinochet and the Catholic Church deteriorated, the government looked to Pentecostal leaders for support. The conservative IMP leadership responded eagerly and positively. Hence, the new Jotabeche cathedral of the Iglesia Metodista Pentecostal (IMP) was officially inaugurated in September 1974 in the presence of General Pinochet and other official representatives of the military dictatorship (Fediakova 2004, p. 259). This happened during the "Te Deum," which was originally a Catholic ritual to bless the new government. The new version, however, was a much broader symbolic mixing of religious and political power and leadership. Two days earlier, 2500 conservative Protestant pastors and church members published a document supporting the September 1973 coup: "The military intervention of the Armed Forces in the historic 
process of our country was the response of God to the prayer of all believers who see in Marxism the maximum darkness of satanic forces." ${ }^{5}$

While some conservative Pentecostal leaders had, like their Protestant counterparts, rallied to the support of the military, their rank-and-file members-overwhelmingly poor and with less education - had mostly supported the leftist Allende government (1970-1973) that was toppled by Pinochet (Tennekes 1985). (Cleary and Sepúlveda 1997, p. 105) concluded that conservative Pentecostal leaders used Pinochet to boost their resources and consolidate their power base-corporatism, again. Meanwhile, the more progressive Pentecostal groups pursued independence from the state and founded new organizations like FASIC (Fundación de Ayuda Social de las Iglesias Cristianas or Foundation for Social Help of the Christian Churches) and SEPADE (Servicio Evangélico para el Desarrollo: Gospel Service for Development), working for socioeconomic development with key social actors of all religions, while the Catholic hierarchy increasingly challenged Pinochet on human rights violations (Fediakova 2004, p. 261). Yet Pentecostals in Chile remained sharply divided, both politically and theologically. They founded multiple umbrella organizations that were unable to coordinate collective evangelization campaigns or maintain an effective political lobby. ${ }^{6}$

Augusto Pinochet, the "perpetual general," (Allende 2003, p. 181) controlled politics in Chile from 1973 to 1990 . Upon the return to democracy, party politics were dominated for twenty years by the progressive Concertación coalition governments of Aylwin (1990-1994), Frei Ruiz-Tagle (1994-2000), Lagos (2000-2006), and Bachelet (2006-2010). The victory of Sebastián Piñera in 2010 was the first for the right in twenty years and more the result of a vote against the Concertación and in favor of change than a vote for Piñera. ${ }^{7}$

Following the return to democracy in 1990, Protestant leaders and their umbrella organizations were sometimes contacted by presidential candidates to court their votes in return for institutional support (Fediakova 2004, p. 264). This was particularly clear during the Lagos administration (2000-2006) and the first Bachelet administration (2006-2010), when progressive Protestant leaders maintained good relations with government officials. ${ }^{8}$ Conservative Protestant leaders had founded their own political party in November 1995, the Alianza Nacional Cristiana (ANC, Christian National Alliance), but its candidates only obtained three percent of the vote in 1997 and the party soon disbanded. Fediakova concluded that it was poorly organized and too narrowly identified with rightwing politics, and that Protestants in Chile were too divided to be represented by only one party (Fediakova 2004, pp. 265-66).

Politicians in Chile did not court Pentecostal voters as openly as in Nicaragua or Venezuela, where the corporatist model dominated (Gooren 2010a, pp. 48, 50, 55ff.). Religion was not an important theme in the 2009-2010 presidential campaign at all, until Bishop Emiliano Soto openly came out in support of Frei of the progressive Concertación coalition. In quick response, IMP Jotabeche Pastor Eduardo Durán Castro and other conservative pastors publicly came out in support of Renovación Nacional candidate Sebastián Piñera. Before going on to win the elections, Piñera made a list of thirty promises to these evangelical leaders, including updating the 1999 Ley de Culto (guaranteeing freedom of worship), greater equality before the law, financial support for Protestant social ministries, and an increase of Protestant chaplains in the armed forces. In 2011, there was grumbling among evangelical leaders that the government was dominated by conservative Opus Dei Catholics and that none of the thirty promises had been kept, illustrating the risks of corporatism. ${ }^{9}$

5 Translated and quoted by (Sepúlveda 1988, p. 312) from the Declaración de apoyo a la Junta de Gobierno de las iglesias evangélicas no. 2 in Posición Evangélica, edited by Pedro Puente (Santiago: mimeo, 1975).

6 Chile interviews 12, 26, 35, and 74; July 13 and August 5, 20, and 24, 2011.

7 (Meyer 2011, p. 5). Bachelet served again as president in 2014-18 and Piñera was again inaugurated as president on March $11,2018$.

8 Chile interviews 5, 12, and 17; June 26, July 13, and July 25, 2011.

9 Chile interviews 12, 15, 28, and 29; July 13, July 21, and August 8 (twice), 2011. 
Institutional politics in Paraguay demonstrated even more continuity than in Chile. General Stroessner based his authoritarian 1954-1989 rule on an iron alliance between the armed forces, the state, and the Colorado Party (Carter 1991, p. 39). ${ }^{10}$ Other political parties were allowed after 1962, but the Colorado Party continued to hold power for almost twenty more years after Stroessner was forced to resign as president in 1989 and the first truly free elections were organized.

When internal strife in the Colorado Party in 1999-2000 led to the assassination of Vice-President Luis María Argaña Ferraro, most people blamed President Raúl Cubas Grau (1998-2003) rather than his Colorado Party (Hanratty and Meditz 2005, p. 5). Under Colorado President Nicanor Duarte (2003-2008), the Paraguayan economy improved, although it remained uneven and highly unequal. Duarte's wife, María Gloria Penayo Solaeche, became a Mennonite in 2001 and soon persuaded her husband to join her. Hence, Duarte became the first non-Catholic President in Paraguay and the Mennonite churches gained their maximum political influence during his government. ${ }^{11}$ The wider Protestant community also benefited from this; the Duarte government was perceived as being favorable to Protestants and maintaining more distance than usual from the Catholic hierarchy. ${ }^{12}$ For the first time in history, Protestants tasted the forbidden fruit of corporatism, finding that involvement in national politics could yield concrete advantages. However, President Duarte's popularity decreased at the end of his term over internal corruption scandals and conflicts with the owner of the $A B C$ Color newspaper and TV channel Telefuturo (Méndez Grimaldi 2009, p. 28; Segovia 2009, pp. 241-43; Thompson 2012).

In September 2007, a center-left coalition of a dozen small parties plus the much bigger Partido Liberal Radical Auténtico (the Liberal Party-PLRA) selected Fernando Lugo as their presidential candidate. The PLRA provided the vice-president, Federico Franco. Born in 1951, Lugo was a supporter of liberation theology and the former bishop of the impoverished northern San Pedro department from 1994 until 2005 (O'Shaughnessy and Díaz 2009, pp. 93-97, pp. 112-13). Because the Paraguayan Protestant community was so small, politicians routinely ignored the non-Catholic vote. Somewhat surprisingly, with a former Roman Catholic bishop running against the first ever female candidate of the Colorado Party, ${ }^{13}$ religion was not an important theme in the 2007-2008 presidential campaign at all, except for the question of whether the Vatican would allow Fernando Lugo to become the first ever bishop to be elected as president in Latin America. ${ }^{14}$ In an exceptionally dirty campaign, even by Paraguayan standards, Lugo was accused of fathering an illegitimate child, orchestrating the murder of a former president's daughter, and "being an active member of the Colombian guerrilla organization FARC" (O'Shaughnessy and Díaz 2009, p. 113). Only the first accusation was true; in 2009, Lugo admitted to fathering a child in a decade-long relationship with Viviana Carrillo, but denied parenthood in all other cases (O'Shaughnessy and Díaz 2009, pp. 127-31). Lugo surprised the Colorado Party and probably many of his supporters by winning the elections.

By 2010, the early popularity of the Lugo government had shattered, partly because voters' expectations had been unrealistically high (Méndez Grimaldi 2009, pp. 30-31; Espínola 2009, pp. 135-44; Beittel 2010, p. 4). Lugo's long affair and illegitimate son created an outcry among his political enemies, but his supporters were not much influenced by these revelations. ${ }^{15}$ Lugo's relationship to the Paraguayan bishops was frosty, but his relations with the Protestant community were not exactly cordial either. Almost all my Pentecostal informants had a negative opinion of Lugo, based mostly on his moral character:

10 For 61 years (1947-2008), party politics in Paraguay were dominated by the Colorado Party, which had been founded in 1887 by Bernardino Caballero to oppose the new Liberal Party.

11 The Duarte administration also included the first ever Mennonite minister, Ernst Bergen (see Bergen 2008).

12 Interview with Dr. Martín Eitzen (Instituto Bíblico Asunción), Oakland University (Rochester, MI); May 14, 2010.

13 Blanca Ovelar had been Minister of Education in the Duarte government (Méndez Grimaldi 2009, p. 28).

14 Paraguay interviews 6, 7, and 10; July 15 (twice) and July 20, 2010. See also (O'Shaughnessy and Díaz 2009, pp. 110-11, 116).

15 Paraguay interview 59 (July 3, 2012); (Beittel 2010, p. 5). 
Lugo enters the presidency as a man of God, a religious man. In the eyes of God, he already failed from here to the moon because of the children, the fact that he's a promiscuous man and all that. He already started badly. It's a personal matter, OK, but next in his job as a politician he didn't do anything either; everything was promises. He abandoned the people who helped him with 85 percent to become president, who were the Liberals. They got tired of him. ${ }^{16}$

This informant indirectly refers to the third position of Pentecostal political involvement, mobilizing the faithful around church leaders, and holds up a Catholic leader, Lugo, as a negative (anti-)example. Another informant reported that Lugo made a loose remark during the electoral campaign that all evangelical church buildings would be converted into daycare centers. ${ }^{17}$ This greatly worried the Protestant leadership. They were already suspicious of a former Catholic bishop sympathetic to liberation theology who was elected president in 2008 with the backing of progressive sectors of civil society. ${ }^{18}$ Similar to Chile, the political culture in Paraguay is intensely personal.

\section{The New Political Ethos: "Because We Are Part of This Society"}

Pentecostal informants in both countries consistently told me that their churches were not interested in politics, kept out of politics, or at best reluctantly allowed their members to get involved in it. However, many informants felt that Pentecostals should get involved in politics to raise its moral standards and to fight corruption. I analyze this new political ethos, its origins, and its possible consequences by referring to the five modes of possible political involvement by Pentecostals outlined above.

Most Chilean Pentecostal informants reported that their churches were just not interested in politics at all. Two informants from the neo-Pentecostal church Tiempo de Dios explicitly wanted Pentecostals to show more involvement in society. ${ }^{19}$ However, a female 22-year-old university student from another independent Pentecostal church resented the fact that their pastor had openly from the pulpit called on members to vote for Sebastián Piñera. ${ }^{20}$ Yet she did want Pentecostals to get more involved in Chilean society; she had participated in massive protest marches in Santiago against the projected Hydro-Aisén hydroelectric plant in a national park and in support of student demands for better access to higher education.

A 40-year-old member of the Iglesia Evangélica Pentecostal (IEP) summarized the difference between the old and the new ethos, or the transition from the first position of Pentecostal political involvement to the third, like this:

In the old days, we the youth were told that we didn't have to get into the universities because the university meant your perdition and the result was that our parents were the janitors in businesses. [..] Nowadays we're making the same mistake with politics. I have the experience of my daughter who wanted to be a spokesperson in her high school. But the [church] youth leader and others next to her wanted to prohibit this as if it were a sin to be a spokesperson for something, of a movement that is fighting for something that's right for students today. We're cutting off a part that she could develop. Perhaps tomorrow, she might become a great political leader or a great religious leader—somebody who makes a difference in religion and in politics. ${ }^{21}$

\footnotetext{
Paraguay interview 58; July 3, 2012.

Paraguay interview 1; July 7, 2010.

18 O'Shaughnessy and Díaz (2009). Lugo was impeached on June 22, 2012 in a controversial two-hour parliamentary session and succeeded by his vice-president Federico Franco (BBC 2012).

19 Chile interviews 62 and 64; August 26 and September 2, 2011.

20 Chile interview 49; August 23, 2011.

21 Chile interview 45; August 6, 2011.
} 
(Fediakova 2004, p. 263) traced the increased willingness of Chilean evangelicals to engage with society to two main factors: the growth of civil society during the early part of the Pinochet dictatorship and the return to democracy in 1990. Her sophisticated study of evangelicals and civil society used participant observation in churches, interviews, and surveys. Seventy percent of her evangelical sample thought that evangelicals should be able to participate in Chilean politics at any level; only 18.5 percent were against this (Fediakova 2004, p. 278). Some of the main motivations given were that "God needs Christian politicians to help with His plan" and "because we are a good example for society." Another informant simply wrote, "because we are part of this society" (Fediakova 2004, p. 279).

Pentecostal laity and leaders alike in both countries stressed that voting was not only a civic right, but an obligation. This represents the first position of Pentecostal political involvement in the overview: trying to convert as many people as possible while voting during elections. A leader in an independent Pentecostal church in Asunción, Paraguay, saw voting during elections as a civic duty of all Pentecostals:

I personally think that people should vote. Fulfill their civic duty. In fact, I believe it is a biblical duty: to elect the authorities, to pray for them. I think we are part of a government system and a social system and we cannot live alienated from those. I don't have a personal involvement in politics. I don't have preferences for political party A or B [..]. But I do think that it is a civic duty of the believer to participate in elections. In my opinion, I think that some believers should be candidates ... [But] I don't defend the position of some governments to accept pastors or religious leaders as candidates, because I believe there is a conflict of interests. [..]

Sometimes I voted because a certain candidate impressed me in some way and I thought they were worthy of my vote as a citizen. But in other cases, I examined the candidates and I felt so frustrated with all of them that I cancelled my vote, I voted blank. I fulfilled my civic and legal duty, but I didn't support any of them. ${ }^{22}$

This man was active in his local neighborhood committee, but not in any political party. Like most Paraguayans, he was thoroughly disillusioned with party politics.

In Chile, a fourth-generation IMP member, 56 years old, likewise thought that evangelicals should be more conscious of the importance of their vote, especially during presidential elections:

Deep down we all have our little preference, whether left or right or center. But the believer knows that all comes from God; he removes kings and raises up kings. The believer who believes in this must logically trust in God and ask Him: "Who does the Lord want to be the next president of our country?"23

There were some political actions that all informants, not just leaders, agreed on as important duties. These included fighting against corruption at all levels of society (including politics), fighting against gay marriage and liberalization of abortion, and fighting to retain, and if possible expand, state recognition of Protestant churches. A minority of Catholic informants in Paraguay and Chile agreed with these points as well (except for the last one), creating favorable conditions for a possible future alliance between conservative Catholics and Protestants. This option is reflected in the second position in the overview of the Pentecostal political involvement: limiting mobilization of the faithful to key moral-ethical issues. This second position now appears to be accepted by a majority of Pentecostal believers across Latin America, although with some significant differences between countries.

A gradual transition from the first type of Pentecostal political involvement to the more active third one is also expressed by founding Pastor Emilio Abreu of the mega-church Centro Familiar de

22 Paraguay interview 44; August 24, 2010.

23 Chile interview 42; August 3, 2011. Note the Biblical reference to Daniel 2, verse 21. 
Adoración (CFA) in Asunción, who stressed that his church aims to help its members bring out "the talent that God gave them." That God-given talent could also be in politics:

EA: I have people who want to get involved in politics and we encourage them because politics needs honest people at this moment. People [..] who can stand firm and say: "Well, we have to do things right."

HG: Are there people who are involved with the parties here?

EA: We have people in the parties; that's right.

HG: But it will be very difficult for them to change the structure of the political parties?

EA: No, we are not trying to change the structure of the party; we change the people and the people will have an influence. ${ }^{24}$

Abreu's perspective mirrors a growing sentiment among Protestant leaders generally that Christians should get involved in politics to raise its moral standards and to fight corruption. One senior Baptist leader said that the people who were currently involved in Paraguayan politics were "aggressive, dishonest, and without scruples." He thought that all Protestants should get more directly involved in politics themselves and leave their old theological dualism of state and church behind. ${ }^{25}$

This new willingness to get more involved in society was also visible in recent Pentecostal leadership struggles in Chile. The Iglesia Metodista Pentecostal (IMP) is the oldest autochthonous Pentecostal church in Latin America and the biggest in Chile, but has received little scholarly attention until recent years. After the death of the authoritarian Bishop Javier Vázquez in 2003, a severe leadership crisis ensued. The first power struggle was between Bishop Roberto López and Bishop Bernardo Cartes; López became the national "presiding" IMP bishop but Cartes remained in office as bishop of Chillán. A schism followed in which all IMP congregations were forced to take sides and church buildings were registered under two different legal personalities. Soon after, Pastor Eduardo Durán Castro of the huge Jotabeche Cathedral in Santiago started making moves to separate himself from both Bishop López and Bishop Cartes. The Jotabeche Cathedral has 7000 members and an estimated monthly tithing income of 120 million pesos, or about US $\$ 240,000$ (equivalent to almost US $\$ 3$ million a year), giving Pastor Durán Castro a strong financial power base. ${ }^{26}$

Of the three IMP leaders, Bishop Roberto López was by far the most open to change. Bishop López supported a stronger role for women in the IMP, the creation of youth groups, more IMP church involvement in Chilean society through NGOs, and more contact with other Pentecostal and Protestant churches, and even with the Roman Catholic Church. ${ }^{27}$ These innovations challenged a century-old conservative classical Pentecostal tradition and generated much controversy. Bishop López was convinced that the IMP must remain in control of finding its place in modern society; without renewal, he felt, the IMP would keep losing members and risk becoming irrelevant in Chilean society. ${ }^{28}$ None of the three IMP factions provided membership statistics, but Bishop López indirectly hinted at membership losses while a staff member of Pastor Durán Castro mentioned steady membership growth. ${ }^{29}$ Judging from their actions during the 2010 elections (see above), Durán Castro and López were more open to indirect involvement in politics than Cartes. Their church support base, which included well-educated staff members who tended to be middle-aged (for Durán Castro) or younger (López), encouraged this new ethos as well.

Young college-educated IMP supporters of Bishop López generally viewed greater church involvement in politics more favorably, although some expressed ambiguity. A 39-year-old female

\footnotetext{
24 Paraguay interview 16; July 27, 2010.

5 Paraguay interview 1; July 7, 2010.

6 Chile interview 27; August 7, 2011.

Chile interviews 19 and 27; July 27 and August 7, 2011.

8 Chile interview 27; August 7, 2011.

9 Chile interview 28; August 8, 2011.
} 
manager participated in a political campaign in 2005 and was shocked by some Pentecostal pastors offering to deliver votes for her: "I'll support your candidate, but he has to guarantee that I'll get a new lot for my church." 30 Obviously, one main risk of the more direct political involvement represented by modes three and four is exactly this type of quid pro quo or, more generally, corporatism.

Not surprisingly, the most elaborate reflections on the pros and cons of direct involvement by Pentecostals in politics (positions four and five) came from a 44-year-old Paraguayan politician who had been a member of the nondenominational Pentecostal church Más que Vencedores (More than Conquerors) for ten years. He got involved in politics as a student leader during the violent 1999-2000 protests against the assassination of Vice-President Argaña Ferraro. Four years later, he had a conversion experience, which he described as "gradual and very rational." In 2009, he became national leader of the small social-democratic party Encuentro Nacional:

The Christian philosophy teaches a lifestyle, not just privately but also publicly. I believe that the Bible teaches us behavior values and the Bible talks often about the leaders of the past with Christian biblical principles. Personally, I believe that I have matured much as a politician and as a person through the teachings of the Bible. It allows me to endure hard and difficult moments; it allows me to have an armored character during the moment of crisis, right? [ ... ]

I believe that politics is an expression of love for your neighbor, a public expression of love for your neighbor. This is what I practice: Aristotle's definition of politics as the search for the common good, the search for the good of all, not just my personal or private good but that of all of society. [ ... ]

I believe that is one of the hardest things to accomplish—not just in politics but in personal life ... Yet a great Christian teaching [is] also that of nonviolence, loving your neighbor. In the Bible, there are all these concepts that, if they were followed in politics, it would be much easier. ${ }^{31}$

The informants advocating greater political commitment of their churches were invariably more highly educated, most were under thirty, and many were also middle-class. The same was true of the supporters of Bishop Roberto López in Chile, the most open to change among the three IMP leadership contenders. Yet Pentecostal pastors in Chile continued to keep their distance from politics. In Paraguay as well, Pastor Emilio Abreu (Centro Familiar de Adoración) and Pastor Emilio Agüero (Más que Vencedores) had very popular TV programs, but neither expressed a personal interest in political involvement, illustrating the historical Pentecostal reserve.

That position contrasts with steps taken by some fellow Protestants in Paraguay. For example, in early 2012, shortly before my second fieldwork period in Asunción, Mennonite pastor Arnoldo Wiens, a well-known media personality thanks to his programs on the Mennonite-owned stations Radio Obedira and TV Red Guaraní, surprisingly gave up his vocation (and his popular TV programs) to launch a presidential campaign. ${ }^{32}$ However, he found it impossible to raise sufficient funding as an independent candidate. Soon after, Wiens announced his support for Horacio Cartes as presidential candidate for the dominant Colorado Party; in return, Cartes put Wiens first on the list of Colorado Senate candidates. The responses to Wiens' candidacy from the Pentecostal community were mixed, with many being very critical. ${ }^{33}$

30 Chile interview 40; July 20, 2011.

31 Paraguay interview 59; July 3, 2010.

32 This is in line with (Levine 2012, p. 116): "Media skills are notable and careers in religious or other broadcasting are increasingly common stepping-stones to political candidacies."

33 Paraguay interviews 71, 75, and 85; July 16, 19, and 25, 2012. 


\section{Conclusions}

This article presented a range of different approaches among Pentecostals to the challenge of political engagement and showed how those approaches have changed over time. Based on that data, we are now in a position to revisit and refine the central features of these positions and explore their broader implications for the relationship between Pentecostals and politics. Below, I further develop my overview of five possible modes of (in)direct involvement by Pentecostal leaders and members in national politics, assessing both their risks and advantages. The easiest and safest position is staying focused on a core evangelical teaching: converting as many people (including politicians and their children) as possible, which should eventually result in positive changes in politics and society. What is new relative to the traditional Pentecostal position in this model of involvement is the conviction that Pentecostals should always vote during elections. This position is nowadays accepted by virtually all Pentecostals in Latin America. It was explicitly espoused by mega-church Pastor Emilio Abreu and was also visible in the small minority of neo-Pentecostal and Vineyard churches in Chile (Fediakova 2004, p. 275). This position takes few risks and has the advantage of keeping members and leaders focused on a core teaching: evangelization. However, the available evidence does not (yet?) show a correlation between high numbers of converts and positive changes in politics and society. The countries in Latin America with the highest population percentages of Protestants are El Salvador (40.8 percent), Nicaragua (35.6 percent), Brazil (30.4 percent), Honduras (28.1 percent), and Guatemala (27.9 percent). ${ }^{34}$ These are also some of the region's poorest countries (apart from Brazil) with some of the world's highest homicide rates.

The second position aims to mobilize the faithful around key moral-ethical issues like divorce, abortion, and same-sex marriage, often in alliance with conservative Roman Catholics. Almost all of my informants in both countries expressed support for this approach. Successful applications of this position have been reported for Brazil, Nicaragua, Chile, Paraguay, and other countries in Latin America where gender roles and social values are contested and gradually changing. However, the government of Cristina Fernández de Kirchner passed a law in July 2010 legalizing same-sex marriage (BBC 2010) in spite of the intense, combined lobbying efforts of Catholics and Protestants. This substantially weakened an ad-hoc ecumenical alliance in Argentina and vividly illustrated one main risk of this position: when a strong lobby is unsuccessful, it can seriously hurt the image of the churches and the leaders involved and create deep divisions between them.

The third possible position of Pentecostal involvement in politics is an extension of the second. It aims to mobilize the faithful by rallying around religious and political leaders who exemplify biblical principles, set a moral example, and explicitly campaign against corruption in politics. Applications of this position can be seen in Guatemala (see below), Bolivia (Wightman 2007), and especially Brazil (Brasil Fonseca 2008, pp. 201-4). This approach offers some important advantages and limits the risks, as stressed by a great number of informants in Paraguay and Chile. The position builds on the older tradition of Pentecostal churches as corporatist groups lobbying for recognition. It allows pastors to mobilize their members, but does not necessarily require them to get personally involved in politics themselves. Many Pentecostals in both Chile and Paraguay wanted to see their churches get more involved with society and with politics, but they did not approve of pastors running as candidates for office. They considered the risks of failure and disillusionment as simply being too high.

Fourth, there is a position of direct political involvement of Pentecostal members (but not leaders), which offers few risks and many advantages, as reflected in the political careers of persons like Ernst Bergen, the Mennonite businessman serving as minister in Paraguay's Duarte government (2003-2008). The main motivation for involvement here is to help one's fellow countrymen; to serve both God and country. Yet Bergen possessed several advantages that few other trailblazers will share. He was a successful and wealthy businessman who had never broken the law. Hence, Bergen could present

34 (Clawson 2012, p. 250), based on 2009 figures from Mandryk (2010). 
himself as a technocrat without party affiliation or personal political ambitions. One suspects that few Pentecostals across Latin America will be able to follow Bergen's example (the literature on Latin America documents no similar cases).

The fifth position, synonymous with Freston's triumphalism or the divine right of evangelicals to govern, was developed by neo-Pentecostal leaders in Guatemala, building on "dominion theology" ${ }^{35}$ This approach aims to get church leaders directly involved in politics as office holders. The main examples so far are two neo-Pentecostal heads of state who aimed to redeem Guatemala's sinful past by setting a moral example, applying biblical principles to solve the country's problems, counteracting Mayan spiritual practices, and following neoliberal economic policies. Yet the Guatemala case also demonstrated the inherent risks of this position. General Efraín Ríos Montt (1982-1983) waged a brutal counterinsurgency against guerrillas and Mayas alike, while Jorge Serrano (1991-1993) combined biblical principles and neoliberal policies only to be impeached for corruption (Garrard Burnett 2010). More recently, neo-Pentecostal pastor Harold Caballeros struggled to create the evangelical party VIVA (Visión con Valores or Vision with Values) and failed to become a presidential candidate, although he was recruited as Minister of Foreign Affairs by Otto Pérez Molina in his 2012-2015 government. ${ }^{36}$ Yet in Chile, no Protestant leader has gotten involved in politics at all, and in Paraguay, most Pentecostals reacted negatively to Wiens' political activism.

In the early stages of Pentecostal growth in both countries, roughly up until the 1960s, staying out of politics (position one) was the safest and also the best way to obtain state recognition, especially for mission churches. In this old ethos, even voting during elections was controversial for dualist theological reasons and for fear of ruffling powerful politicians' feathers or attracting negative attention (Lalive d'Epinay 1969, pp. 118-19). In Chilean Pentecostalism, this position dovetailed with its traditional ethos of a clear separation between church and world. However, it was altered by some conservative leaders of the Iglesia Metodista Pentecostal who began angling for state recognition by organizing yearly "Te Deum" celebrations in their Jotabeche "cathedral" soon after General Pinochet's 1973 coup. Freston considered this to be a form of political imitation of the dominant Roman Catholic Church, clearly reflected even in the Catholic terms used (Te Deum, cathedral). In Paraguay, being apolitical remained the best way for Protestant churches to obtain official state recognition during the Stroessner dictatorship (1954-1989).

Several factors contributed to the transition from the old to the new ethos of moderate political involvement in Chile and Paraguay. With the flourishing of civil society in both countries in the 1980s and 1990s, new opportunities for the political involvement of Protestant churches opened. ${ }^{37}$ The return to democracy added the promise of obtaining favors from political candidates in return for support (Freston's corporatism with its concomitant risks). Modern mass media like television and internet made believers more aware of politically active Protestants and Pentecostals in Guatemala and especially Brazil. ${ }^{38}$ Increasing levels of education and upward social mobility among Pentecostals likely influenced many committed believers to favor greater political involvement from their churches as well. Yet Pentecostal leaders in both countries remained reluctant to get directly involved in politics themselves, likely perceiving the risks (both to themselves and to their churches) to be greater than the potential rewards. Together, the Paraguay and Chile cases can illuminate why Pentecostal leaders in countries as varied as Mexico, Venezuela, Peru, Argentina, and Uruguay tend to stay out of politics.

35 Based on Genesis (1, verse 26), in which God gave "dominion" over the earth to mankind, the dominion movement started in the United States "among socially conservative Christians who sought to gain influence or control over secular civil government through political action. It was characterized by striving for a nation to be governed by Christians or by biblical principles" (Holvast 2009, pp. 161-62).

36 Pérez (2011). Caballeros, who has written four books and holds both an MBI and an MIR, is obviously a successful pastor, yet struggles to find his place in Guatemalan politics. See also (O'Neill 2010, pp. xix, 203). President Pérez Molina ultimately resigned over a corruption investigation on September 3, 2015 (BBC 2015).

37 (Levine 2012, p. 122), in fact, saw the main role of Protestant churches in the strengthening of civil society through building communities, not through direct (partisan) political involvement.

38 See Gooren (2018) for an extended analysis of the impact of mass media on the churches in Paraguay. 
The Chilean case demonstrated that even a century-long history of autochthonous Pentecostalism and Pentecostal influence on mainstream Protestant churches does not necessarily lead to a strong Pentecostalization of civil society or, one phase later, of political culture. The traditional dualist Pentecostal theology was one main reason for this fact, as was the long Pinochet dictatorship (1973-1990). However, most neo-Pentecostals in Chile did want to see more societal involvement of their churches and the same was true among younger members of the autochthonous IMP and IEP. The Paraguay case showed that even recent Pentecostal growth could lead to Pentecostalizing effects on mainline Protestantism, but also, perhaps more surprisingly, that this was a two-way process. The Mennonites' economic power led them, by way of Radio Obedira and TV Red Guaraní, into politics. One trailblazer, Mennonite businessman Ernst Bergen, became a government minister, but Arnoldo Wiens's Senate candidacy showed that direct political involvement of Protestant leaders was still controversial in Paraguay. As Pentecostals gradually become part of mainstream society, as happened in Guatemala and is still continuing to happen in Chile, younger and increasingly better-educated members will want their churches to get more involved in society and to follow the lead of other, more directly engaged Protestants, profoundly affecting their churches' theology, leadership, organization, evangelization, and political practices in the process.

Acknowledgments: I conducted fieldwork in Asunción, Paraguay (June-August 2010 and 2012) and Santiago de Chile (June-August 2011). My individual research project, "The Pentecostalization of Religion and Society in Paraguay and Chile," was funded by the Pentecostal-Charismatic Research Initiative (PCRI), which was sponsored by the John Templeton Foundation and administered by the University of Southern California under grant number 13839 (see http:/ / crcc.usc.edu/initiatives/pcri). Special thanks go to Martin H. Eitzen, Daniel Jordan Smith, and Richard L. Wood for their critical comments on earlier versions of this article. Additional thanks are due to three anonymous peer reviewers and to Roger G. Robins, the editor of this special edition.

Conflicts of Interest: The author declares no conflicts of interest.

\section{References}

Allende, Isabel. 2003. My Invented Country: A Nostalgic Journey through Chile. New York: HarperCollins.

Barrett, David B., George T. Kurian, and Todd M. Johnson. 2001. World Christian Encyclopedia, 2nd ed. Oxford: Oxford University Press.

BBC (British Broadcasting Corporation). 2010. Argentine Gay Couple Tie Knot under New Marriage Law. Available online: http:/ /www.bbc.co.uk/news/world-latin-america-10823279 (accessed on 29 March 2013).

BBC (British Broadcasting Corporation). 2012. Removal of Paraguay's President Lugo Draws Strong Reactions. Available online: http:/ /www.bbc.co.uk/news/world-latin-america-18564206 (accessed on 29 March 2013).

BBC (British Broadcasting Corporation). 2015. Renuncia el presidente de Guatemala, Otto Pérez Molina. Available online: http://www.bbc.com/mundo/noticias/2015/09/150903_renuncia_perez_molina_guatemala_ corrupcion_aw (accessed on 2 June 2013).

Beittel, June S. 2010. Paraguay: Political and Economic Conditions and U.S Relations. Washington, DC: Congressional Research Service of the Library of Congress. Available online: http:/ /www.dtic.mil/cgi-bin/GetTRDoc? $\mathrm{AD}=\mathrm{ADA} 514199$ (accessed on 15 June 2013).

Bergen, Ernst. 2008. Jumping into Empty Space: A Reluctant Mennonite Businessman Serves in Paraguay's Presidential Cabinet. Intercourse: Good Books.

Brasil Fonseca, Alexandre. 2008. Religion and Democracy in Brazil: A Study of the Leading Evangelical Politicians. In Evangelical Christianity and Democracy in Latin America. Edited by Paul Freston. New York: Oxford University Press, pp. 163-206.

Carter, Miguel. 1991. El papel de la iglesia en la caída de Stroessner. Asunción: RP Ediciones.

Clawson, David L. 2012. Latin America and the Caribbean: Lands and Peoples, 5th ed. New York: Oxford University Press.

Cleary, Edward L., and Juan Sepúlveda. 1997. Chilean Pentecostalism: Coming of Age. In Power, Pentecostals, and Politics in Latin America. Edited by Edward L. Cleary and Hannah Stewart-Gambino. Boulder: Westview Press, pp. 97-121.

Duarte, Rogelio. 1994. El desafío protestante en el Paraguay. Asunción: Centro Cristiano de Comunicación Creativa. Duarte, Rogelio. 2001. Historia y mensaje de los bautistas en el Paraguay. Asunción: Etigraf. 
Espínola, Gabriel. 2009. La situación política y las tareas principales para el gobierno de Lugo. In Gobierno Lugo: Herencia, gestión y desafíos. Edited by Luis Rojas Villagra. Asunción: BASE Investigaciones Sociales, pp. 131-44.

Fediakova, Evguenia. 2004. "Somos parte de esta sociedad": Evangélicos y política en el Chile post autoritario. Política 43: 253-84.

Freston, Paul. 2001. Evangelicals and Politics in Asia, Africa and Latin America. Cambridge: Cambridge University Press.

Garrard Burnett, Virginia. 2010. Terror in the Land of the Holy Spirit: Guatemala under General Efrain Ríos Montt, 1982-1983. New York: Oxford University Press.

Gooren, Henri. 2002. Catholic and Non-Catholic Theologies of Liberation: Poverty, Self-Improvement, and Ethics among Small-Scale Entrepreneurs in Guatemala City. Journal for the Scientific Study of Religion 41: 29-45. [CrossRef]

Gooren, Henri. 2010a. Ortega for President: The Religious Rebirth of Sandinismo in Nicaragua. European Review of Latin American and Caribbean Studies 89: 11-27. [CrossRef]

Gooren, Henri. 2010b. The Pentecostalization of Religion and Society in Latin America. Exchange 39: 355-76. [CrossRef]

Gooren, Henri. 2013. The Growth and Development of Non-Catholic Churches in Paraguay. In Spirit and Power: The Global Impact of Pentecostal Growth. Edited by Richard Flory, Donald E. Miller and Kimon Sargeant. New York: Oxford University Press, pp. 83-98.

Gooren, Henri. 2015. The Growth and Development of Non-Catholic Churches in Chile. Review of Religious Research 57: 191-218. [CrossRef]

Gooren, Henri. 2018. Mass Media Impact on Christian Churches in Paraguay. Paper presented at the Annual Meeting of the Society for the Scientific Study of Religion, Las Vegas, NV, USA, October 27.

Hanratty, Dannin M., and Sandra W. Meditz. 2005. Paraguay: A Country Profile; Washington, DC: Federal Research Division for the Library of Congress. Available online: http:/ /cweb2.loc.gov/frd/cs/profiles/Paraguay.pdf (accessed on 28 October 2008).

Holland, Clifton L. 2006. Paraguay. In Worldmark Encyclopedia of Religious Practices: Volume 3, Countries M-Z. Edited by Andrew Riggs. Detroit: Thomson Gale, pp. 205-9.

Holvast, René. 2009. Spiritual Mapping in the United States and Argentina, 1989-2005: A Geography of Fear. Leiden: Brill.

Johnstone, Patrick, and Jason Mandryk. 2001. Operation World, 6th ed. Carlisle: Paternoster Lifestyle.

Lalive d'Epinay, Christian. 1969. Haven of the Masses: A Study of the Pentecostal Movement in Chile. London: Lutterworth.

Levine, Daniel H. 1986. Religion and Politics in Comparative Perspective. Comparative Politics 19: 95-122. [CrossRef]

Levine, Daniel H. 2012. Politics, Religion, and Society in Latin America. Boulder: Lynne Rienner.

Mandryk, Jason. 2010. Operation World, 7th ed. Colorado Springs: Biblical Publishing.

Masías-Hinojosa, Víctor Hugo, Paola Ramírez-Pérez, and María Inés Winkler-Müller. 2008. Construcción de identidad en personas convertidas a la Iglesia Metodista Pentecostal de Chile. Forum: Qualitative Social Research 9: 1-29.

Méndez Grimaldi, Idilio. 2009. Batalla contra el imperialismo, la oligarquía y la corrupción. In Gobierno Lugo: Herencia, gestión y desafíos. Edited by Luis Rojas Villagra. Asunción: BASE Investigaciones Sociales, pp. $25-42$.

Meyer, Peter J. 2011. Chile: Political and Economic Conditions and U.S. Relations. Washington, DC: Congressional Research Service of the Library of Congress. Available online: http:/ /www.fas.org/sgp/crs/row / R40126. pdf (accessed on 11 November 2011).

O’Neill, Kevin L. 2010. City of God: Christian Citizenship in Postwar Guatemala. Berkeley: University of California Press.

O'Shaughnessy, Hugh, and Edgar Venerando Ruiz Díaz. 2009. The Priest of Paraguay: Fernando Lugo and the Making of a Nation. London and New York: Zed Books.

Parker, Cristián. 2000. Religion and Culture. In Chile in the Nineties. Edited by Cristián Toloza and Eugenio Lahera. Stanford: Stanford University Press, pp. 617-60.

Patterson, Eric. 2005. Religious Activity and Political Participation: The Brazilian and Chilean Cases. Latin American Politics and Society 47: 1-29. [CrossRef] 
Pérez, Rodrigo. 2011. Pérez confirma que Harold Caballeros será el canciller. Siglo XXI, November 12.

Plett, Rodolfo. 1988. El protestantismo en el Paraguay. Asunción: FLET/IBA.

Segovia, Diego. 2009. La necesaria democratización de las comunicaciones. In Gobierno Lugo: Herencia, gestión y desafíos. Edited by Luis Rojas Villagra. Asunción: BASE Investigaciones Sociales, pp. 239-53.

Sepúlveda, Juan. 1988. Pentecostal Theology in the Context of the Struggle for Life. In Faith Born in the Struggle for Life: A Re-Reading of Protestant Faith in Latin America Today. Edited by Dow Kirkpatrick. Grand Rapids: Eerdmans, pp. 299-318.

Tennekes, Hans. 1985. El movimiento pentecostal en la sociedad chilena. Amsterdam and Iquique: Cultural Anthropology VU University/CIREN.

Thompson, Warren. 2012. Evangelizing the State: Mennonite Brethren Technocrats in Paraguayan State Reform, 2003-2008. Albuquerque: MA Thesis in Sociology, University of New Mexico.

Wightman, Jill M. 2007. Healing the Nation: Pentecostal Identity and Social Change in Bolivia. In Conversion of a Continent: Contemporary Religious Change in Latin America. Edited by Timothy J. Steigenga and Edward L. Cleary. New Brunswick: Rutgers University Press, pp. 239-55.

(C) 2018 by the author. Licensee MDPI, Basel, Switzerland. This article is an open access article distributed under the terms and conditions of the Creative Commons Attribution (CC BY) license (http://creativecommons.org/licenses/by/4.0/). 